\title{
Desain Lapisan Tipis Optik Menggunakan Metode Algoritma Evolusi
}

\author{
Wahyu Darmawan \\ Prodi Teknik Elektro, Universitas Buddhi Dharma, \\ Tangerang, Indonesia \\ wahdar@gmail.com
}

\begin{abstract}
Abstrak- Metode the Family Competition Evolutionary Algortihms (FCEA) untuk membuat desain sistem lapisan tipis telah dipelajari. FCEA menggabungkan dua jenis rekombinasi dan tiga jenis mutasi. Modified discrete recombination dan intermediate recombination untuk rekombinasinya dan decreasing base gaussian mutation, self adaptive gaussianmutation, self adaptif cauhcy muatation untuk proses mutasinya. Hasil numerik memperlihatkan bahwa FCEA dapat menghasilkan parameter awal berupa ketebalan d, dengan jumlah lapisan dan indeks bias material lapisan tipis yang sudah ditentukan. Fungsi Merit (FM) menyatakan hasil keakurasian relatif kecil, sekitar 1.5 sampai dengan 0.56. Pendekatan FCEA sangat fleksibel dan dapat dimanfaatkan untuk berbagai macam aplikasi.
\end{abstract}

Keywords - the Family Competition Evolutionary Algorithms (FCEA), lapisan tipis, ketebalan, indeks bias, Fungsi Merit (FM), optik.

\section{Pendahuluan}

Dalam setiap alat-alat optik biasanya dilapisi oleh lapisan tipis yang berfungsi sebagai reflectance maupun transmittance. Proses pelapisan (coating) optik sangat diperlukan dalam memanipulasi nilai reflectance maupun transmittance bagi setiap cahaya yang melewati setiap peralatan optik. Dan unjuk kerja lapisan ditentukan oleh interferensi yang terjadi pada setiap batas lapisan [1].

Untuk mendesain thin film optik, diperlukan penentuan parameter coating $(\mathrm{n}, \mathrm{t}, \mathrm{N})$ yang masing -masing mewakili indeks bias, tebal dan jumlah lapisan thin film. Ada banyak metode yang digunakan untuk menentukan parameter coating, metode yang banyak digunakan adalah refinement dan transformasi Fourier [2,3,4]. Pada metode refinement, jika penentuan parameter awal tidak tepat menyababkan hasil akhir yang tidak akurat [2]. Sedangkan untuk transformasi Fourier hanya dapat digunakan pada antireflection coating $[2,4]$.

Untuk memecahkan masalah penentuan parameter awal, beberapa konsep telah diperkenalkan, antara lain artificial intellegent, neural nets, fuzzy method dan evolutionary algorithms [5]. Metode yang terakhir ini adalah metode pencarian stokastik serta optimalisasi heuristik berdasarkan teori seleksi alam. Metode ini merupakan pengembangan dari metode algortma genetik yaitu seleksi, reproduksi, rekombinasi dan mutasi $[1,2,5]$

\section{TINJAUAN PUSTAKA}

\section{A. Family Competition Evolutionary Algorithms}

Langkah dasar dalam metode FCEA adalah penentuan $\mathrm{P}$ individu solusi awal yang dipilih secara acak yang berfungsi sebagai input. Setiap individu terkandung parameter indeks bias, ketebalan dan jumlah lapisan [2] . Kemudian setiap individu diseleksi sesuai dengan Fungsi Meritnya FM(x) yang didefinisikan sebagai :

$$
F M(x)=\sqrt{\frac{\sum_{k=1}\left(R_{\varepsilon}\left(\lambda_{k}\right)-R_{\varepsilon}\left(A_{k}\right)\right]^{2}}{2}}
$$

Dimana $\operatorname{Rc}(\lambda \mathrm{k})$ dan $\operatorname{Rc}(\lambda \mathrm{k})$ masing -masing adalah reflektansi hasil perhitungan dan reflektansi target. Dan L adalah jumlah variasi $\lambda$. Proses yang baik adalah jika nilai FM minimum [1]

Setelah proses seleksi awal maka dilakukan peroses rekombinasi dan satu jenis mutasi untuk masing -masing individu, kemudian dilakukan proses seleksi lagi yaitu dengan cara membandingkan antara individu orang tua dengan dan individu anak (Family Competition) dan membuang individu yang mempunyai nilai FM yang lebih besar. Proses berulang untuk individu yang berbeda terhadap semua populasi. Kemudian dilanjutkan untuk jenis mutasi yang berbeda.

\section{B. Seleksi}

Kemudian dilakukan proses seleksi dengan membuang sebagian individu yang memiliki FM besar dan menggandakan individu yang memiliki nilai FM kecil dengan menggunakan metode Range Base Fitness Assigment (RFBA) [9,10] . Dalam RFBA setiap individu yang memiliki nilai FM kecil memiliki nilai RFBA tinggi.

\section{Rekombinasi}

Proses selanjutnya adalah rekombinasi dengan mengawinkan dua individu dengan menggunakan berbagai strategi rekombinasi dan menghasilkan dua individu anak yang baru. Dalam hal ini kita menggabungkan dua proses rekombinasi sekaligus. Yaitu Modified Discrete 
Recombiantion dengan mengawinkan kedua individu untuk dijadikan orang tua dengan kontribusi $80 \%$ dan $20 \%$ untuk masing-masing individu dan Intermediate Recombination mengikuti persamaan

$$
\begin{aligned}
& d^{c}=d^{\prime}+x\left(d^{2}-d^{l}\right) \\
& w^{c}=w^{2}+x\left(w^{2}-w^{l}\right)
\end{aligned}
$$

Dimana d tebal optik, $\chi$ faktor skala dipilih random, dan $\mathrm{w}$ adalah mewakili parameter $v, \psi, \sigma .[1,6]$

Indeks c, 1 dan 2 masing -masing adalah untuk anak, orang tua 1 dan 2.

\section{Mutasi}

Proses terakhir dari algorithma evolusi adalah mutasi dengan menambahkan atau mengurangkan setiap parameter yang telah direkombinasi. Terdapat tiga kali proses mutasi yaitu, SelfAdaptive Gaussian Mutation (SAGM), untuk ketebalan d dan parameter v. Self-Adaptive Cauchy Mutation untuk parameter tebal optik d dan parameter $\psi$ dan Decreasing-Based Gaussian Mutation untuk parameter tebal optik d dan parameter $\sigma$. $[1,6]$ Mutasi pertama :

$$
\begin{aligned}
& v_{j}=v_{j} \theta^{(\pi N(0,1)+\tau N(01)} \\
& d_{j}=d_{j}+v_{j} N_{j}(0,1)
\end{aligned}
$$

Mutasi kedua adalah : $\psi_{j}=\psi_{j} e^{(\pi N(0,1))+\tau N(0,1)}$
$d_{j}=\alpha_{j}+\psi_{j} c_{j}(1)$

Sedangkan mutasi yang ketiga adalah :

$$
\begin{aligned}
& \sigma^{\sigma}=\gamma \sigma^{j} \\
& d_{j}-d_{j}+\sigma^{\sigma} N_{j}(0,1)
\end{aligned}
$$

\section{Metode}

Desain dan pemrograman menggunakan $\mathrm{C}$, adapun proses pembuatan thin film menggunakan metode Physical Vapour Deposition (PVD) dengan subtrate lensa bahan FC5, FDS90 dan TaFD30,produksi SCHOTT Ag untuk 3 sampel. Material thin film meliputi MgF2, Alumina dan SiO2.

Temperatur yang digunakan $1500 \mathrm{C}, 1300 \mathrm{C}$ dan $800 \mathrm{C}$ untuk masing -masing MgF2, Alumina dan $\mathrm{SiO} 2$.

Tekanan Udara vakum yang digunakan adalah 0,0001 Torr. Dengan metode elektron beam.

Pengukuran reflektance menggunakan Simadzu Optical reflectance UV-VIS.

\section{PEMBahasan}

Material substrate FC-5 $(\mathrm{n}=1.488)$, didapat FM 1.504 , Material FDS-90 $(n=1.847)$ didapat FM = 1.04, material TaFD-30 ( 1.62) , didapat FM $=0.56$, ketiganya dilakukan dengan iterasi yang sama yaitu 100x.

Tabel 1. Perbandingan ketebalan lapisan tipis antara simulasi dan eksperimen ns $=1.488$

\begin{tabular}{|c|c|c|c|c|c}
\hline Lapisan & Material thin-film & $\mathbf{n t}$ & $\mathbf{d s}(\mathbf{n m})$ & $\mathbf{d e}(\mathbf{n m})$ & $\mathbf{d e}-\mathbf{d s} \mid \mathbf{X} \mathbf{1 0 0 \%}$ \\
\hline 1 & $\mathrm{MgF} 2$ & 1.38 & 98.72 & 94.56 & $4.23 \%$ \\
\hline 2 & $\mathrm{SiO} 2$ & 2.05 & 110.92 & 105.49 & $5.15 \%$ \\
\hline 3 & $\mathrm{Al} 2 \mathrm{O} 3$ & 1.63 & 34.24 & 32.75 & $1.56 \%$ \\
\hline
\end{tabular}

Tabel 2. Perbandingan ketebalan lapisan tipis antara simulasi dan eksperimen ns $=1.847$

\begin{tabular}{|c|c|c|c|c|c}
\hline Lapisan & Material thin-film & $\mathbf{n}$ & $\mathbf{d s}(\mathbf{n m})$ & $\mathbf{d e}(\mathbf{n m})$ & $\mathbf{d e}-\mathbf{d s} \mid \mathbf{X} \mathbf{1 0 0 \%}$ \\
\hline 1 & $\mathrm{MgF} 2$ & 1.38 & 78.078 & 90.761 & $13.97 \%$ \\
2 & $\mathrm{SiO} 2$ & 2.05 & 124.314 & 121.862 & $2.02 \%$ \\
\hline 3 & $\mathrm{Al} 2 \mathrm{O} 3$ & 1.63 & 157.665 & 166.689 & $5.41 \%$ \\
\hline
\end{tabular}

Tabel 3. Perbandingan ketebalan lapisan tipis antara simulasi dan eksperimen ns $=1.620$

\begin{tabular}{|c|c|c|c|c|c}
\hline Lapisan & Material thin-film & $\mathbf{n}$ & $\mathbf{d s}(\mathbf{n m})$ & $\mathbf{d e}(\mathbf{n m})$ & $|\mathbf{d e}-\mathbf{d s}| \mathbf{X} \mathbf{1 0 0 \%}$ \\
\hline 1 & $\mathrm{MgF} 2$ & 1.38 & 93.579 & 93.12 & $0.49 \%$ \\
\hline 2 & $\mathrm{SiO} 2$ & 2.05 & 154.304 & 146.6 & $5.26 \%$ \\
\hline 3 & $\mathrm{~A} 2 \mathrm{O} 3$ & 1.63 & 23.491 & 27.5 & $14,58 \%$ \\
\hline
\end{tabular}


Disini terlihat tingkat penyimpangan desain terhadap ekperimen cukup kecil, Kesalahan terbesar terjadi jika ketebalan material yang dinginkan cukup tipis.

\section{PENUTUP}

\section{A. Kesimpulan}

Penentuan parameter awal sampai didapat nilai yang mendekati dalam desain lapisan tipis dapat dicapai dengan algoritma evolusi tanpa harus dilakukan lebih dari seratus kali iterasi. Penambahan iterasi lebih dari itu tidak membawa dampak signifikan bagi penurunan nilai FM. Nilai FM yang kecil didapat dengan membuat ketebalan awal dibawah 500 $\mathrm{nm}$. Akan sangat efesien jika ditambah proses refinement.

Percobaan ini hanya dilakukan terhadap variasi ketebalan saja, agar lebih mudah dalam proses aplikasinya, disebabkan kita dengan mudah menentukan bahan lapisan tipis sesuai yang kita inginkan.

Dari ketiga desain menguatkan bahwa pencarian secara random terhadap parameter awal menggunakan metode FCEA lebih efesien dibandingkan dengan metode algortima genetik konvensional yang hanya terdiri dari satu kali proses rekombinasi dan mutasi. Metode ini sudah dapat digunakan dalam desain lapisan tipis tanpa perlu lagi proses refinement.

\section{DAFTAR PUSTAKA}

[1] R.J.W. Hodgson, Memetic algortihm approach to thin film optical coating design, University of Ottawa, Ontario Canada (2001).

[2] S. Martin, J.Rivory, M. Shoenauer,"Synthesis of optical multilayer systems using genetic algorithms,", App.Opt.34, 2247-2254 (1995).

[3] R.R. Wiley, "Understanding and using fourier transform thin film design without advanced calculus". 35th annual Technical Conference Proceeding (1992).

[4] P.G. Verly, A.V. Thikhonravov, M.K. Trubetskov,"Efesien refinement algorithm for the synthesis of inhomogeneous optical coating", App.Opt.40,3256-3267(2001).

[5] F. Streichert, Introduction to evolutionary algorithms, University of Tuebingen.

[6] J.M. Yang, C.Y. Kao,"Efficient evolutionary algorithms for the thin-film synthesis of inhomogeneous optical coatings",App.Opt.40, 3256-3267 (2001).

[7] H.A. McLeod, Thin-film optical filters (Hilger, Bristol, 1967).

[8] A.Thelen, Design of optical interference coatings (McGraw-Hill Optical and Electro-optical Eng. Series, 1998).

[9] D.E. Goldberg, Genetic algorithms in Search, Optimation and machine Learning (Addison-Wesley, Reading, Mass. 1989). (2001) 